Grażyna Pol (iD) https://orcid.org/0000-0001-5329-360X

Narodowe Centrum Kultury

adres e-mail: gpol@nck.pl

Zuzanna Maciejczak-Kwiatkowska (D) https://orcid.org/0000-0002-1560-6887

Narodowe Centrum Kultury

e-mail: zmaciejczak@nck.pl

\title{
Kogo nie interesuje kultura (instytucjonalna)? Segmentacja uczestników kultury
}

Abstract

\section{Who is Not Interested in (Institutional) Culture? Segmentation of Cultural Participants}

Referring to the role of institutions in the field of culture and concepts of participation and (un)participation in culture, we sought to answer the question of who can be defined as a potential audience of cultural, above all musical, institutions. In the text we justify why it is worth to use survey and segmentation studies to identify and describe cultural (un)participants, despite the limitations of both methods. We present the segmentation prepared by the National Centre of Culture which was developed based on a nationwide survey carried out for the purposes of the Moniuszko Year. We refer to the motivation and barriers to participation characteristic of each of the five distinguished segments, that is: distanced pragmatists, connected omnivores, those remaining in the comfort zone, visitors of aesthetes, immersed in culture. In the conclusion part we present which of distinguished segments, in the first place, could be effectively encouraged to participate in the culture by institutions such as operas and philharmonics.

Keywords: participation, segmentation, institutional culture, (un)participation

Słowa kluczowe: partycypacja, segmentacja, kultura instytucjonalna, uczestnictwo, (nie)uczestnictwo 


\section{Wprowadzenie}

Trywialne byłoby stwierdzenie, że instytucje działające w polu kultury chcą wiedzieć, kto uczestniczy w organizowanych przez nie przedsięwzięciach. Mniej banalne jest pytanie, czy mają tę wiedzę. A także czy zdobywają ją w sposób systematyczny i ustrukturyzowany? A może korzystają wyłącznie z intuicji i obserwacji pracujących w niej osób? Nie ma łatwych odpowiedzi na te pytania. Niektóre instytucje prowadzą badania ankietowe, liczą uczestników, analizują trendy, obserwują inne podmioty, a także poszukują wiedzy, posiłkując się innymi metodami, często zaczerpniętymi z obszaru badań marketingowych. Rezultatem jest obraz uczestnika, który nie zawsze jest precyzyjny i spójny. Instytucje kultury, tak jak i wiele innych aktorów życia społecznego, stają przed wyzwaniem związanym ze zmieniającymi się modelami uczestnictwa w kulturze, czy szerzej - życia społecznego. Kultura ulega deinstytucjonalizacji, jej źródła są rozproszone i często umiejscowione poza organizacyjnymi ramami instytucji kultury. Jednocześnie zwiększa się znaczenie oddolnego tworzenia kultury czy roli grup nieformalnych powiązanych zainteresowaniami [por. Bachórz et al. 2014: 5-6].

Nieustannym zmartwieniem zarówno osób kształtujących politykę kulturalną, jak i organizatorów wydarzeń, jest uczestnictwo w kulturze". Tal Feder i Tally Katz-Gerro [2012: 360-361] wskazują troskę instytucji publicznych o zapewnianie obywatelom dostępu do kultury jako jeden z dwóch uniwersalnych celów polityki kulturalnej [Wiśniewski, Kukołowicz 2017: 96].

Andrzej Tyszka już w latach osiemdziesiątych XX wieku pisał o potrzebie poznania uczestników (jednocześnie sceptycznie odnosząc się do klasyfikacji uczestników wydarzeń kulturalnych) [por. Tyszka 1980: 113-118].

Stan aktywności kulturowej jednostek lub stopień i styl ich uczestnictwa - to tylko jeden z aspektów istnienia kultury. Niemniej zaangażowanie kategorii pojęciowej „uczestnictwa w kulturze" ma ogromne znaczenie dla rozpoznania i rozumienia zorganizowanego i stymulowanego rozwoju kultury, upowszechniania kultury, jej demokratyzacji - a w dalszej konsekwencji dla realizacji wszelkiej polityki kulturalnej. Znajomość sposobów uczestniczenia w kulturze i samej jego istoty jest pierwszym metodologicznym zadaniem z punktu widzenia zadań poznawczych wobec kultury [Tyszka 1981: 137].

Uczestnictwo i nieuczestnictwo w kulturze elitarnej, wymagającej wysokiego kapitału kulturowego nabywanego w rodzinie i szkole [por. Bourdieu 1990, 2005] często tłumaczy się statusem społeczno-ekonomicznym badanych. Proponujemy inne podejście do tej problematyki. Wyodrębnialiśmy segmenty, analizując między innymi stosunek badanych do muzyki poważnej czy uczestnictwo w kulturze instytucjonalnej. Mamy nadzieję, że może ono być pomocne dla instytucji, również tych 
kojarzonych z tak zwaną kulturą wysoką, jeśli chcą się adaptować do nowych oczekiwań uczestników kultury oraz zmiennych warunków społeczno-ekonomicznych, procesów indywidualizacji, kolonizowania doświadczeń jednostki przez zjawiska cyfrowej rzeczywistości. Spróbujemy pokazać, kogo instytucje dystansują i dlaczego oraz kogo mogą zdefiniować jako potencjalną publiczność. Wykorzystamy w tym celu analizę segmentacyjną.

\section{Nowe wyzwania dla instytucji w polu kultury}

Diagnozy polskich badaczy związane ze zmieniającymi się modelami uczestnictwa w kulturze oraz wnioski z własnych badań, dotyczące tychże, zebrali i opisali autorzy raportów Instytutu Kultury Miejskiej w Gdańsku [Bachórz et al. 2014; Bachórz, Stachura 2015]. W dalszej części artykułu będziemy odwoływać się do ich ustaleń. Jedna $\mathrm{z}$ tez we wspomnianych publikacjach mówi o deinstytucjonalizacji kultury, to znaczy, że zaangażowanie w kulturę nie musi się realizować w ramach instytucji, w specjalnie wydzielonym do celów kulturalnych czasie i miejscu [Bachórz et al. 2014: 5]. W komentarzu do raportu „Punkty styczne: między kulturą a praktyką nie uczestnictwa” Marek Krajewski, opisując zmieniające się modele uczestnictwa, zwraca uwagę, że:

zmniejsza się znaczenie zobowiązań normatywnych, które czyniły uczestnictwo w kulturze instytucjonalnej warunkiem bycia pełnoprawnym członkiem zbiorowości, osobą kulturalną, przedstawicielem określonych kategorii społecznych. Zwiększa się zakres oddolnego tworzenia samej kultury, samodzielnego organizowania sobie czasu wolnego, zawiązywania społecznych zbiorowości osadzonych we wspólnocie zainteresowań, a nieokreślonych przez zmienne społeczno-demograficzne. (...) co istotne, te nowe modele uczestnictwa w kulturze, bardzo często realizują się poza stereotypowo rozumianą sferą kultury, a raczej (i również) w czasie pracy czy w ramach aktywności sportowych i społecznych [Bachórz et al. 2014: 5-6].

Również w refleksji teoretycznej odchodzi się od hierarchicznej i kanonicznej wizji kultury symbolicznej [Bachórz, Stachura 2015: 8]. Przywołuje się pojęcie poszerzonego pola kultury, akcentuje się sieciowość, więziotwórczość, relacyjność, rezygnuje się z traktowania kultury jako odświętniej, autotelicznej i wyłącznie symbolicznej [[Bachórz, Stachura 2015: 8]. Diagnozy dotyczące poszerzonego pola kultury nie są jednak równoznaczne z unieważnieniem znaczenia instytucji kultury.

Nie oznacza to oczywiście, że sektor zaczął się „zwijać”. (...) Instytucje kultury do realizacji własnych celów sięgają po narzędzia i instrumenty „spoza kultury”, i odwrotnie - instytucje „spoza kultury” realizowały swoje cele, posiłkując się narzędziami kulturowymi [Bachórz et al. 2014: 11-12]. 
Ponadto powstają nowe instytucje kultury, często korzystające ze znacznych środków finansowych, w tym filharmonie i opery [por. Afeltowicz et al. 2018], ale też muzea i inne instytucje związane $\mathrm{z}$ diagnozowanym przez badaczy poszerzaniem pola kultury w stronę dziedzictwa kulturowego [por. Kukołowicz, Wiśniewski 2017].

Pomimo opisanych wyżej zjawisk, ale też „wszystkożerności” kulturowej [Peterson, Kern 1996], nadal istnieją wyrafinowane nisze kojarzone z prestiżowością i ekskluzywizmem [Bachórz, Stachura 2015: 65]. Dodatkowo udział w wydarzeniu kulturalnym jest przez ich uczestników inaczej wartościowany niż aktywność podejmowana w domu - „wyjście” jest wyżej cenioną formą aktywności. Niezależnie od okazji, skali imprezy czy wydarzenia (może to być na przykład wyjście do kina) mają one nierzadko w subiektywnym odczuciu status odświętności i ważnego momentu w osobiście kształtowanym życiu kulturalnym [Bachórz et al. 2014: 45].

Rozpatrywane jako jeden $\mathrm{z}$ aktorów w polu kultury instytucje kultury, w tym instytucje artystyczne, nadal, i to jest nasze założenie, mają istotną rolę do odegrania. Dane sondażowe z 2018 roku wskazują na nieznaczny wzrost w ciągu ostatnich ośmiu lat, jeśli chodzi o odsetek Polek i Polaków deklarujących odwiedzanie instytucji: kin, teatrów, galerii i muzeów [CBOS 2018] ${ }^{1}$. Wyzwaniem dla instytucji staje się jednak adaptacja do zmieniających się modeli uczestnictwa w kulturze. Badania sugerują, że istnieje rozbieżność między tym, co uczestnicy kultury o wyrafinowanych potrzebach postrzegają jako interesujące, a tym, co za wartościowe i atrakcyjne uznaje kadra instytucji kultury. Na przykład osobom młodym i wykształconym tak zwana kultura wysoka, prezentowana w tradycyjnych instytucjach kultury, wydaje się przestarzała i nieciekawa, podobnie jak niska kultura oferowana przez telewizję [Bachórz, Stachura 2015: 65].

Podejmowane są próby przebudowania instytucji zgodnie z potrzebami odbiorców, w taki sposób, aby umożliwić wyjście poza tak zwane wyspowe uczestnictwo w zinstytucjonalizowanej kulturze jedynie niedużej części obywateli [Bachórz, Stachura 2015: 66]. Zwrócili na to uwagę Tomasz Kukołowicz i Rafał Wiśniewski w tekście pt. „Pięć kierunków poszerzania pola kultury, czyli uwagi o współczesnej polityce kulturalnej":

Dzisiaj państwo polskie finansuje działalność kilku tysięcy instytucji kultury, z których przynajmniej część proponuje wartościową ofertę artystyczną w przystępnych cenach, a czasem wręcz za darmo. Niestety, statystyczny Polak, stojąc przed wyborem, czy iść do galerii sztuki, czy do galerii handlowej, bez wahania wybierze to drugie (zob. Drozdowski, Fatyga, Filiciak,

${ }^{1}$ Na utrzymujący się od lat stabilny wzrost wskaźników uczestnictwa w kulturze instytucjonalnej (jeśli chodzi o odsetek obywateli podejmujących daną aktywność chociaż raz w minionym roku) wskazał Piotr Tadeusz Kwiatkowski podczas konferencji „Badania publiczności w instytucjach kultury". Odsetki różnią się jednak od pomiaru (instytucji badawczej, czasu przeprowadzenia sondażu). Jest to ciekawa obserwacja w kontekście tez o deinstytucjonalizacji kultury. 
Krajewski, Szlendak 2014). Wobec tego faktu instytucje kultury stają przed koniecznością walki o widza lub też jej bardziej współczesnej odmiany - kształtowania publiczności (audience development) [Kukołowicz. Wiśniewski 2017: 96].

\section{Badania (nie)uczestnictwa, czyli potencjalnej publiczności}

Badania (nie)uczestnictwa były już realizowane, nie wyważamy otwartych drzwi. Pojęcie (nie)uczestnictwa zapożyczyłyśmy z publikacji $W$ poszukiwaniu punktów stycznych. Rekonstrukcja dyskursu o problemach (nie)uczestnictwa w kulturze, w której autorzy piszą o partycypacji w kulturze jako kontinuum, odrzucając zerojedynkowy podział na uczestnictwo i nieuczestnictwo [Bachórz, Stachura 2015: 29].

Autorzy raportów dotyczących tego zjawiska zaznaczają, że (nie)uczestnictwo jest zależne od sytuacji i cyklu życia. Mimo to, z punktu widzenia instytucji, nadal zasadne pozostają próby rozpoznania, jakie uwarunkowania, bariery i ograniczenia wiążą się z podejmowaniem aktywności w zmieniającym się kontekście instytucjonalnym.

W badaniach kultury zwraca się uwagę na takie przyczyny (nie)uczestnictwa, jak: bariery strukturalne związane z habitusem powiązanym z daną klasą społeczną [Gdula, Lewicki 2018], utrudnienia specyficzne dla ośrodków peryferyjnych, związane z zależnościami „centrum-peryferia” [zob. Jacyno et al., 2018; Szlendak et al. 2019], osamotnienie, zbyt absorbujące relacje zawodowe czy rodzinne [Bachórz et al. 2014]. Wskazuje się też na nadpodaż oferty i związany z tym chaos komunikacyjny [Bachórz, Stachura 2015].

O bariery pyta się także wprost w badaniach sondażowych. Przy czym niektórzy badacze wskazują, że część z deklarowanych trudności jest de facto racjonalizacją i próbą usprawiedliwienia się, a nie realną przeszkodą:

Wydaje się, że deklarowane utrudnienia maskują realne powody nieuczestnictwa, czyli fakt, że ludzie nie organizują swojego czasu wokół kultury, a jest ona zazwyczaj mało istotnym dodatkiem do uznawanych za istotniejsze codziennych aktywności [Bachórz, Stachura 2015: 37].

W tym miejscu warto jednak dodać, że ważny argument $\mathrm{w}$ tej dyskusji podniesiono w analizach warszawskiego badania uczestnictwa w kulturze z 2017 roku [Kotnarowski, Piechocki 2019]. Autorzy na podstawie analiz regresji stwierdzili, że istnieje zależność między deklarowanymi barierami a sytuacją badanych. Oznacza to, że brak czasu, zmęczenie i brak pieniędzy (najczęściej podawane przez badanych powody nieuczestnictwa) nie zawsze są pozorną barierą. Szczegółowy opis procedury badawczej, za pomocą której badacze doszli do przytoczonych wniosków, znajduje się w cytowanym raporcie. Po przeprowadzeniu analiz regresji i zestawieniu ich z deklaracjami badanych autorzy konstatują: 
Czy to, że nie uczestniczymy w kulturze z powodu braku czasu lub finansów, to zwykła wymówka? Wyniki naszych analiz wskazują, że niekoniecznie. Model statystyczny wykazał, że im więcej mamy obowiązków, w tym mniej dziedzin kultury się angażujemy. Co prawda są zmienne, które w większym stopniu determinują „kulturową wszystkożerność” niż brak czasu, niemniej czas przeznaczany na pracę, naukę i obowiązki domowe należy do najsilniejszych determinant praktyk kulturalnych. Względna spójność pomiędzy deklaracjami a wynikami modeli regresyjnych dotyczy także wymiaru finansowego. Zarówno w deklaracjach, jak i w modelu finanse należą do kluczowych czynników wpływających na uczestnictwo [Kotnarowski, Piechocki 2019: 48].

Analizy przeprowadzone w Warszawie nie wskazały podobnej zależności, jeśli chodzi o takie bariery jak stan zdrowia, sprawowanie opieki i otoczenie infrastrukturalne, co zachęca do prowadzenia podobnych analiz oraz pogłębiania tych wyników badaniami o jakościowym charakterze. Niemniej jednak uznajemy te dane za argument na rzecz tezy, że pytania o bariery uczestnictwa w badaniach sondażowych, mimo wszystkich ograniczeń związanych z tą metodą badawczą, sygnalizują realne problemy, które napotykają potencjalni uczestnicy kultury.

\section{Segimentacja w kulturze}

W ostatnich latach coraz częściej sięga się w badaniach uczestnictwa w kulturze po stosowaną w marketingu segmentację. Opisał ją po raz pierwszy Wendell R. Smith. Jest to strategia pozwalającą na wyróżnienie typów odbiorców i zaoferowanie im produktów adekwatnych do potrzeb [Smith 1956: 3-8]. Celem badań segmentacyjnych w szerokim ujęciu [por. Punj, Stewart 1983: 135] jest wyodrębnienie grup jednostek nazywanych segmentami, które mają wspólne cechy, na przykład przyzwyczajenia, zwyczaje nabywcze, poglądy, charakterystykę społeczno-demograficzną. Podział na grupy pozwala na dostosowanie oferty do specyfiki segmentu [por. Kotler 1994: 243]. Oprócz zalet praktycznych związanych ze sprawdzonymi w biznesie sposobami wykorzystania wyników właśnie w marketingu kultury segmentacja pozwala też wychwycić inne niż makrospołeczne i demograficzne uwarunkowania uczestnictwa, co tworzy potencjalnie przestrzeń do poszerzenia grup uczestników kultury. Umożliwia instytucjom wyjście poza dzielenie uczestników na oczywiste kategorie, choćby te związane z wiekiem. Pozwala spojrzeć na różnorodność uczestników kultury, biorąc pod uwagę inne kryteria. Segmentacja nie jest jednak pozbawiona wad, na co zwróciła uwagę Anna Giza-Poleszczuk podczas debaty na ostatnim Kongresie Badaczy Rynku i Opinii². Zgodnie z przedstawionymi przez nią argumentami segmentacja

${ }^{2}$ Nagranie debaty jest dostępne online, http://wyborcza.pl/7,154385,24091614,kongres-badaczy-czy-marketing-wzmacnia-podzialy-spoleczne-w.html [odczyt: 3.06.2019]. 
w przypadku badań marketingowych może być postrzegana jako wzmacniająca podziały społeczne. Giza-Poleszczuk zwróciła uwagę, że to, jakie segmenty są wyodrębnione w badaniach, zależy od tego, o jakie cechy, opinie, wyznawane wartości, aspiracje itp. pytamy respondentów i jakich związków korelacyjnych szukamy. Kolejnym krokiem po wyborze odpowiedniej grupy dla naszych usług lub produktów jest prezentowanie tej grupy i jej cech szerokiej publiczności jako kontekstu konsumpcji - jak powiedziała Giza-Poleszczuk - „opowiadamy ludziom o nich samych" i próbujemy ich przekonać, że pasuje do nich nasz produkt bądź usługa, jednocześnie utwierdzając ich w przekonaniu, że prezentowana grupa jest odrębna od innych i wyjątkowa ${ }^{3}$. W przypadku marketingu w kolejnym kroku dostarczamy owej grupie „totemy” podkreślające jej odmienność od innych, czyli marki.

Jeśli przyjąć, że te wątpliwości są zasadne w kontekście marketingu, pozostaje pytanie, czy ta obawa jest realna w przypadku segmentacji uczestników kultury. Rozważenie tego problemu wymagałoby, jak sądzimy osobnego (i potrzebnego) tekstu, jednak warto mieć te zastrzeżenia na uwadze, po pierwsze stosując segmentację w badaniach kultury jako metodę, a po drugie, wykorzystując ją do działań programowych i komunikacyjnych. Potencjalnie segmentacja może służyć do tego, aby programować działania sprzyjające spotkaniu z sobą różnych „socjowysepek”.

Pewnym zabezpieczeniem przed wytwarzaniem i utrwalaniem podziałów poprzez wykorzystywanie badań segmentacyjnych, jest mnogość segmentacji w kulturze, na podstawie których mogą być następnie prowadzone działania menedżerów kultury ${ }^{4}$. Każda $\mathrm{z}$ nich bierze pod uwagę inne kryteria, wyodrębniając nieco inne grupy. Wybrane próby segmentacji z lat 2014-2017 zostały zebrane i opisane w publikacji Narodowego Centrum Kultury - Rocznik Kultury Polskiej 2017[Retko-Bernatowicz 2017].

Kryteria, które są brane pod uwagę do wyodrębnienia grup, zależą od przedmiotu i celu badania. W przypadku badań Biblioteki Narodowej tym kryterium było czytelnictwo (nie tylko liczba przeczytanych książek, ale też między innymi społeczne relacje towarzyszące obiegowi książki, emocje i postawy towarzyszące lekturze) [Koryś et al. 2017] . Wyodrębniono w ten sposób następujące segmenty: generalnie nieczytający, czytelnicy tradycyjni, czytelnicy zaangażowani, czytelnicy emocjonalnie zdystansowani, nieczytający książek. Z kolei w badaniach NCK realizowanych na potrzeby projektowania programu „Niepodległa”, kryterium segmentacji był stosunek względem Święta Niepodległości i preferowane sposoby obchodzenia

${ }^{3}$ Za relację z debaty i zwrócenie uwagi na opisany problem dziękujemy dr Małgorzacie Retko-Bernatowicz.

${ }^{4}$ Podobny argument przeciwko tezie, że segmentacja wzmacnia podziały społeczne, przytoczył Michał Kociankowski na wspomnianej debacie. Jego zdaniem podziały są możliwe, kiedy ludzie mają poczucie przynależności do grupy (segmentu) i ma on dla nich znaczenie. Jest tyle segmentacji w zależności od produktów i usług, że trudno budować na tej podstawie tożsamość.

${ }^{5}$ Metodologia: $\mathrm{N}=3149$, ogólnopolska próba reprezentatywna, min. 15 lat, technika CAPI. 
stulecia [Kwiatkowski et al. 2016] ${ }^{6}$. Scharakteryzowano następujące grupy: obojętni, typowi, światowi ambasadorzy, przywiązanie do tradycji, obywatelscy, rozrywkowi.

Oprócz szczegółowych segmentacji nakierowanych na konkretny obszar kultury realizowane są także badania segmentacyjne dotyczące uczestnictwa w szeroko rozumianej kulturze. W cytowanych wyżej badaniach warszawskich kryteriami wyodrębnienia mieszkańców Warszawy były: doświadczenia kulturalne, opinie i oczekiwania dotyczące sztuki oraz wartości uznawane za ważne w życiu [Płachecki red. 2019] ${ }^{7}$. Badanie to jest przykładem jednym z wielu odnoszących się do mieszkańców dużego miasta, jednak w 2019 roku zespół badaczy [Szlendak et al. 2019] zaproponował również segmentację osób uczestniczących w kulturze w małych i średnich miastach ${ }^{8}$. Do wyodrębnienia segmentów uczestników brano pod uwagę intensywność indywidualnych praktyk kulturalnych (związanych z czytaniem, oglądanie, słuchaniem muzyki, klikaniem i „bywaniem”) oraz uspołecznione sposoby uczestnictwa, czyli zbiorowe praktyki kulturalne związane ze wspólnym bywaniem na wydarzeniach kulturalnych czy u przyjaciół/znajomych. W wyniku analiz wyodrębniono cztery kategorie uczestników kultury w mniejszych miastach: kulturowo pasywnych, uspołecznionych tradycjonalistów, cyfrowych indywidualistów oraz kulturalnie aktywnych.

Obok badań dotyczących mieszkańców wybranych miast, w ostatnich latach były też realizowane badania segmentacyjne na reprezentatywnych próbach dorosłych Polaków dotyczące uczestnictwa w kulturze. W badaniach opracowanych w raporcie „Kulturalna hierarchia. Nowe dystynkcje i powinności w kulturze a stratyfikacja społeczna" [Bachórz et al. 2016] ${ }^{9}$ kryteriami wyróżniającymi były: pozycja społeczna (wykształcenie, wykształcenie rodziców, sytuacja zawodowa, powierzchnia mieszkaniowa, dochód) i nowy kapitał kulturowy (suma czterech składowych, czyli postawy prospołecznej, czynników osobowościowych, zaangażowania towarzyskiego, aktywności obywatelskiej). Tym sposobem scharakteryzowano: biegających społeczników, indywidualnych graczy, gustownych średniaków, nieufnych analogowców i wspólnotowych działkowców. Inną próbą ogólnopolskiej segmentacji uczestników kultury była ta zaprezentowana w raporcie pt. „Badanie segmentacyjne uczestników kultury" [MHP/Polin/NIFC/Smartscope 2016], gdzie podstawą podziału zbiorowości były: oczekiwania wobec czasu wolnego (potrzeby) oraz korzystanie z oferty instytucji i kultury domowej (zachowania). Na tej podstawie wyróżniono: ludowych tradycjonalistów, zdobywców wiedzy, aspirujący mainstream,

${ }^{6}$ Metodologia: $\mathrm{N}=1500$, ogólnopolska próba reprezentatywna, min. 15 lat, technika CAPI.

7 Metodologia: $\mathrm{N}=8700$, próba mieszkańców Warszawy, min. 15 lat, technika CAPI.

${ }^{8}$ Metodologia: $\mathrm{N}=605$, próba mieszkańców sześciu celowo dobranych miast nieobjętych procesem metropolizacji, technika wywiadów kwestionariuszowych.

${ }^{9}$ Metodologia: $\mathrm{N}=1000$, próba dorosłych Polaków, technika CATI. 
wycofanych, konsumentów kultury instytucjonalnej, poprawnych konformistów, młodych uciekinierów, przymusowych domatorów, sensualnych.

\section{Metody i techniki}

W badaniu Narodowego Centrum Kultury do interpretacji zebranych danych i identyfikacji segmentów wykorzystano podejście post hoc, zwane też opisowym, w którym analizy zmierzające do wyodrębnienia poszczególnych grup na względnie jednorodne klasy są wykonywane na gotowym zbiorze danych. Inaczej niż w przypadku segmentacji a priori, nazywanej również predykcyjną, gdzie jeszcze przed badaniem decyduje się o liczbie segmentów, jak i ich charakterystykach [por. Walesiak 2000: 2].

Do budowy segmentacji wykorzystano zagregowane dane z sondażu zrealizowanego przez Centrum Badania Opinii Społecznej techniką wywiadu ankieterskiego wspomaganego komputerowo. Pogłębione analizy statystyczne dotyczące uczestnictwa w kulturze zostały zlecone w 2019 roku analitykom z firmy Realizacja Sp. z o.o. pracującym pod kierownictwem Macieja Orłowskiego. Umożliwiły one zaobserwowanie zależności między deklaracjami, opiniami i cechami badanych. Badanie sondażowe ze względu na dobór próby miało charakter badania reprezentatywnego, którego wyniki można uogólnić na całą populację. Kwestionariusz zawierał pytania dotyczące uczestnictwa w kulturze muzycznej (przede wszystkim instytucjonalnej) oraz znajomości postaci i twórczości Stanisława Moniuszki. Do realizacji projektu powodem stała się obchodzona w 2019 roku dwusetna rocznica urodzin Stanisława Moniuszki ${ }^{10}$.

Do prezentowanego modelu segmentacji opisowej wykorzystaliśmy hierarchiczną metodę skupień. Wyboru czynników dokonałyśmy, analizując tablicę aglomeracji i dendrogram obrazujący bliskość poszczególnych zmiennych ze względu na przyjętą metodę aglomeracyjną. Wszystkie zmienne wejściowe wykorzystane do analizy były niezależne, a liczba segmentów nieznana. Wynikiem analiz stał się podział na grupy oraz wyodrębnienie kryteriów najsilniej różnicujących badaną zbiorowość.

Każda z opisanych wcześniej segmentacji uczestników kultury brała inne cechy, opinie i deklaracje badanych pod uwagę jako kryterium wyodrębniania segmentów. Jak wspominałyśmy, zależało to od celów, przedmiotu i założeń badań. Nasza segmentacja powstała na podstawie danych zebranych w ramach badań realizowanych

${ }^{10}$ Uchwałą Sejmu Rzeczypospolitej Polskiej z dnia 20 lipca 2018 r. (M.P. poz. 731) rok 2019 ogłoszono Rokiem Stanisława Moniuszki. Szerzej badanie zostało zaprezentowane w raporcie „Stanisław Moniuszko - znany, lecz nieobecny. Opinie Polaków na temat twórczości i postaci kompozytora w dwusetną rocznicę jego urodzin". Raport jest dostępny na stronie: www.nck.pl/badania/projekty badawcze [odczyt: 3.06.2019]. 
na potrzeby Roku Moniuszki i to zasadniczo warunkuje uzyskany efekt. Statystycznie wyodrębniłyśmy grupy, biorąc pod uwagę:

- uczestnictwo w kulturze instytucjonalnej;

- aktywności muzyczne;

- stosunek do muzyki poważnej (wobec „powinności” jej słuchania oraz samo słuchanie i uczestnictwo w koncertach).

Wyznaczone w ten sposób segmenty to odpowiednio pięć skupień przekładających się na typy uczestników kultury.

\section{Segimentacja uczestników kultury}

Zaproponowana przez nas segmentacja jest ciekawą hybrydą opisanych wyżej podejść do badania kultury i uczestnictwa ${ }^{11}$. Z jednej strony uwzględnia motywacje i bariery związane z tym wycinkiem uczestnictwa w kulturze, który kojarzy się z tradycyjnym, wąskim rozumieniem kultury, kulturą artystyczną oraz kulturą „odświętną”, a niecodzienną (opery, filharmonie, muzyka poważna), związaną z wydarzeniami, a nie „kulturą domową”. Z drugiej strony obejmuje ona wcześniej opisane, wybrane zjawiska związane z poszerzeniem pola kultury. Umieściłyśmy bowiem dane w szerszym kontekście praktyk kulturalnych: nie tylko odbioru sztuki, ale i własnej aktywności (muzykowania), uczestnictwa online w kulturze (słuchanie muzyki przez streaming) czy festynach. Takie podejście wynikało wprost z praktycznych celów i kontekstu badania. Nie interesowała nas opera/filharmonia i muzyka poważna ze względu na to, że to jest kultura wysoka i tylko uczestnictwo w niej jest naszym zdaniem warte uwagi ze względu na przedmiot badań.

Poniżej prezentujemy krótką charakterystykę wyodrębnionych grup.

Pierwszym wyróżnionym segmentem są zdystansowani pragmatycy ( $26 \%$ próby). Segment ten charakteryzuje się stosunkowo niskim odsetkiem uczestników wydarzeń kulturalnych. Osoby z tej grupy, jeśli już decydują się na udział w wydarzeniu, wybierają najczęściej festyn, kino lub koncert muzyki innej niż klasyczna. Żaden ze zdystansowanych pragmatyków nie uczestniczył w koncercie muzyki poważnej. Najczęstszą motywacją do udziału w rozmaitych przedsięwzięciach kulturalnych

${ }^{11}$ Wydaje się, że jest ona bliska „postrozszerzeniowej” koncepcji uczestnictwa w kulturze, sformułowaną w odpowiedzi na problemy z operacjonalizacją uczestnictwa w kulturze w ujęciu „rozszerzonym". Owe trudności polegają na tym, że definiując uczestnictwo jako wszelkie praktyki uspołeczniające, trudno określić granice: można w jego skład włączać wiele praktyk a ostatecznie wyboru dokonują badacze. Badania uczestnictwa prowadzone konsekwentnie w ujęciu „poszerzeniowym” są w ograniczonym stopniu przydatne dla instytucji kultury i innych aktorów zainteresowanych rozwojem publiczności i zwiększaniem lub pogłębianiem uczestnictwa. Rekonstrukcję obydwu podejść oraz propozycję badań w ujęciu postrozszerzeniowym [zob. Szlendak et al. 2019; Płachecki red. 2019]. 
było poszukiwanie rozrywki. Istotnie częściej ${ }^{12}$ od pozostałych ankietowanych odpowiadali, że nie zastanawiają się nad powodami swojego udziału w wydarzeniach.

$\mathrm{W}$ porównaniu $\mathrm{z}$ innymi segmentami tworzący go respondenci najrzadziej deklarowali, że przeczytali w ciągu ostatniego roku co najmniej jedną książkę dla przyjemności oraz wskazywali, że muzykują indywidualnie lub w grupie. Najczęściej preferowanym gatunkiem muzycznym jest w tej grupie disco polo (43\%) oraz pop (11\%), a 8\% zaznaczyło, że nie słucha muzyki w ogóle. Zdystansowani pragmatycy nie korzystają z serwisów z muzyką cyfrową. Zapytani o powody nieuczestnictwa w ciągu ostatnich 12 miesięcy w koncertach muzyki klasycznej oraz przedstawieniach operowych ${ }^{13}$ wskazywali, że nie interesuje ich to. Mówili także o braku czasu oraz niedostatecznej zasobności portfela.

Grupę tworzą istotnie częściej, w porównaniu ze strukturą całej próby, osoby starsze, powyżej 65. roku życia (35\%). Żadna z płci nie dominuje w jej charakterystyce. Wśród tworzących go respondentów istotnie częściej odnotowano osoby z wykształceniem podstawowym oraz zasadniczym zawodowym, robotników wykwalifikowanych, osoby bezrobotne, jak również rencistów i emerytów. Ankietowani należący do tego segmentu przypuszczalnie borykają się z problemami finansowymi, a nabyte kompetencje kulturowe uniemożliwiają odczytanie części treści niesionych przez sztukę. Zdystansowani pragmatycy są niezainteresowani ofertą instytucji muzycznych. Poszukują głównie oderwania od spraw codziennych, a wydarzenia kulturalne traktują jako okazję do spotkań towarzyskich.

Drugi wyodrębniony segment stanowią podłączeni wszystkożercy (11\% próby). Cechuje ich wysoka aktywność kulturalna egzemplifikowana między innymi odsetkiem korzystających przynajmniej raz w okresie ostatnich dwunastu miesięcy z oferty różnych miejsc związanych z życiem kulturalnym. Wśród najczęściej odwiedzanych przez nich instytucji dominuje kino, koncerty muzyki innej niż klasyczna, festyny oraz muzea i domy kultury. Istotnie częściej, w porównaniu ze wskazaniami ogółu badanych, poszukują rozrywki (59\%). Inne towarzyszące im powody uczestnictwa w wydarzeniach kulturalnych to chęć oderwania się od codzienności, spędzenia atrakcyjnie czasu z innymi lub poszerzenia własnych horyzontów.

Podłączeni wszystkożercy deklarowali w zdecydowanej większości (80\%), że przeczytali w ciągu ostatniego roku dla przyjemności przynajmniej jedną książkę.

${ }_{12}$ Licząc istotności w odniesieniu do kategorii - posłużyłyśmy się testem proporcji „z-test” z poprawką na wagę i poziomie istotności 0,05 .W odniesieniu do średnich posługiwaliśmy się testem F. Raportowany poziom istotności określa prawdopodobieństwo tego, że co najmniej średnia dla jednej $\mathrm{z}$ grup różni się od innej grupy. Za istotne uznaliśmy różnice $>=0,95$.

${ }_{13}$ Motywacje do uczestnictwa badano wykorzystując odpowiedzi na pytanie: Kiedy uczestniczy Pan(-i) w wydarzeniach kulturalnych bądź odwiedza instytucje kultury, to robi to Pan(-i) przede wszystkim... Powody nieuczestnictwa mierzono $z$ wykorzystaniem odpowiedzi na pytanie: Powiedział(-a) Pan(-i), że w ciągu ostatnich 12 miesięcy w ogóle nie uczestniczył(-a) Pan(-i) w koncertach muzyki klasycznej/poważnej i nie było(-a) Pan(-i) w operze/filharmonii. Które z tych powodów o tym zdecydowały? 
W odniesieniu do innych wyodrębnionych grup stosunkowo często wskazywali, że muzykują indywidualnie (28\%) oraz w grupie (21\%). Cechą wyróżniającą segment jest to, że wszyscy słuchają muzyki z wykorzystaniem płatnych serwisów internetowych. Jako gatunek muzyczny pierwszego wyboru najwięcej osób wskazało rock (21\%), pop (21\%) oraz rap (12\%). Żaden ankietowany nie preferował muzyki religijnej, bluesa oraz muzyki poważnej. Ponadto 4\% zaznaczyło, że słucha innego, niesklasyfikowanego rodzaju muzyki, co może sugerować, że poszukują alternatywnych trendów muzycznych. Zapytani o powody nieuczestnictwa w koncertach muzyki klasycznej oraz przedstawieniach operowych odpowiadali, że ich to nie interesuje, nie mają na to czasu oraz że czują się nieswojo w takich miejscach.

Segment charakteryzuje młody wiek jego członków, w niemal połowie to osoby do 35. roku życia. Odsetek tworzących go ankietowanych powyżej 65. roku życia jest znikomy (1\%). Grupę tą tworzą w większości mężczyźni (63\%). Istotnie częściej znajdziemy wśród podłączonych wszystkożerców osoby z wykształceniem wyższym, kadrę kierowniczą, pracowników administracyjno-biurowych, jak również uczniów i studentów. W porównaniu z innymi wyodrębnionymi typami uczestników do wielu codziennych czynności wykorzystują internet. Istotnie częściej niż przedstawiciele pozostałych wyodrębnionych grup deklarowali, że ich sytuacja materialna jest dobra. Omijają instytucje kulturalne, lecz z innych powodów niż zdystansowani pragmatycy. Odmiennie korzystają z kultury i poszukują alternatywnych środków przekazu.

Kolejny segment to pozostający w strefie komfortu (40\% próby). Tworzących go ankietowanych można określić mianem statystycznego Polaka czy statystycznej Polki, ponieważ rozkład ich odpowiedzi jest zbliżony do rozkładu odpowiedzi ogółu badanych. W ciągu ostatniego roku, spośród pozadomowych aktywności kulturalnych, najczęściej uczestniczyli w festynie, odwiedzili kino, uczestniczyli w koncercie muzyki innej niż klasyczna, byli w domu kultury oraz bibliotece. Najczęstszą wskazywaną motywacją do uczestnictwa w wydarzeniach kulturalnych była chęć rozrywki, oderwania się od codzienności czy spędzenia czasu z innymi w atrakcyjny sposób.

Co najmniej jedną książkę przeczytało dla przyjemności w ciągu ostatniego roku 73\% respondentów tworzących ten segment. Charakteryzuje ich umiarkowane zamiłowanie do grania na instrumentach czy śpiewania - indywidualnie muzykuje 22\%, a w grupie 13\%. Słuchają najczęściej zespołów, które klasyfikują jako przedstawicieli nurtu disco polo (23\%) oraz pop (21\%). Wśród respondentów z tego segmentów nie odnotowano osób słuchających muzyki klasycznej. Brak zainteresowania tą dziedziną, niedostatek wolnego czasu oraz trudności z dojazdem, badani wskazywali jako powody nieuczestnictwa w koncertach muzyki klasycznej oraz przedstawieniach operowych.

Rozkład wieku w opisywanym segmencie odpowiada rozkładowi z całej próby. Grupę tę charakteryzuje wyższy odsetek kobiet (59\%) i osób z wykształceniem średnim (35\%). Żadna grupa społeczno-zawodowa nie jest w nim reprezentowana 
istotnie częściej niż w całej próbie. Odznaczają się upodobaniem do tego, co modne i popularne. Na podstawie danych można przypuszczać, że do grupy tej należą osoby chcące być na bieżąco, niewyróżniające się ponadprzeciętną wiedzą, ale aspirujący, którzy zinternalizowali postawę człowieka kulturalnego.

Czwarty segment stanowią bywalcy esteci (12\% próby). Są oni istotnie częściej zainteresowani zwiedzaniem obiektów historycznych, muzeów, bibliotek i domów kultury. Do uczestnictwa motywuje ich najczęściej chęć rozrywki lub oderwania się od codzienności, poszerzenia własnych horyzontów lub spędzenia czasu z innymi w atrakcyjny sposób.

Tworzący go respondenci czytają książki dla przyjemności. W ciągu ostatnich 12 miesięcy $84 \%$ z nich przeczytało co najmniej jedną publikację. Charakteryzuje ich umiarkowane wysokie zamiłowanie do gry na instrumentach i śpiewu - indywidualnie muzykuje 35\%, w grupie zaś 21\%. Najczęściej słuchają muzyki, którą klasyfikują jako pop (15\%), rock (13\%) oraz muzyka klasyczna (10\%). Pytani o powody nieuczestnictwa w koncertach muzyki klasycznej lub przedstawieniach operowych wskazywali na brak czasu, trudności z dojazdem, dalekie usytuowanie instytucji od miejsca zamieszkania, jak również to, że nie mają z kim pójść.

Rozkład wieku wśród przedstawicieli tego segmentu jest zbliżony do rozkładu z próby. Istotnie częściej znajdziemy w tej grupie osoby z wykształceniem wyższym oraz emerytów. Dane sugerują, że do grupy tej należą osoby nastawione na budowanie relacji towarzyskich z innymi. Osoby, które traktują wyjście do instytucji kultury przede wszystkim jako wydarzenie społeczne, pretekst pozwalający utrzymać czy pogłębiać relacje międzyludzkie.

Piąty, ostatni, segment to zanurzeni w kulturę (11\% próby). Tworzący go ankietowani wykazali duże zaangażowanie w wydarzenia kulturalne. Niemal wszyscy odwiedzili w ciągu ostatnich dwunastu miesięcy muzeum, kino, uczestniczyli w koncercie muzyki innej niż klasyczna lub festynie. Niewiele mniej odwiedziło bibliotekę oraz brało udział w koncercie muzyki klasycznej. Jako najczęstszą motywację do udziału w wydarzeniach kulturalnych wskazywali istotnie częściej niż pozostali, chęć poszerzenia swoich horyzontów, przeżycie estetyczne oraz doświadczenie czegoś wyjątkowego. Motywacje towarzyszące uczestnictwu w wydarzeniach są wyróżnikiem tej grupy. Odnoszą się do poszukiwań wewnętrznych i potrzeby doznań estetycznych i pozazmysłowych.

Rozkład wieku i płci wśród przedstawicieli tego segmentu jest zbliżony do rozkładu z próby z lekkim, statystycznie nieistotnym, akcentem na kobiety oraz osoby do 34 roku życia. Istotnie częściej znajdziemy zaś wśród zanurzonych w kulturę osoby z wyższym wykształceniem, kadrę kierowniczą oraz uczniów i studentów. Do gry na instrumentach czy śpiewu przyznaje się niemal połowa ankietowanych tworzących ten segment. Indywidualnie muzykuje $46 \% \mathrm{z}$ nich, a w grupie $40 \%$. Jako najczęściej słuchany gatunek muzyczny badani wskazywali muzykę klasyczną (18\%), pop (17\%), rock (14\%) czy jazz (6\%). Preferowanie muzyki poważnej jest symptomatyczne dla 
ankietowanych z segmentu bywalców i zanurzonych. Wśród tworzących trzy pozostałe grupy nie odnotowano osób preferujących muzykę klasyczną

Zanurzeni w kulturę akcentują trudności z podjęciem decyzji i wybraniem jednego wydarzenia spośród wielu istniejących propozycji. To w płynny sposób koresponduje z powodami uczestnictwa, które w tej grupie odnoszą się zwykle do wrażeń estetycznych.

\section{Podsumowanie}

Zadaniem instytucji kultury, które chcą się odnaleźć w szybko zmieniającej się sytuacji, staje się diagnozowanie oczekiwań uczestników kultury, otwieranie się na nowe potrzeby, definiowanie nisz, do których chce się dotrzeć, stwarzanie szans uczestnictwa i partycypacji grup dotychczas słabiej uczestniczących w danym obszarze kultury. Jak pokazuje raport „Efekt Bilbao/kult cargo. Nowe instytucje kultury w Polsce", nie jest to łatwe zadanie, szczególnie dla tak niszowych i często dystansujących instytucji, jak filharmonie czy opery [zob. Afeltowicz et al. 2018: 283-287]. Jak piszą autorzy analiz, w porównaniu z muzeami, galeriami czy „kulturowymi multipleksami" filharmonie w mniejszym stopniu dają możliwość mieszania „niskich” i „wysokich” form [Afeltowicz et al. 2018: 275].

Rozbijając nasze pojęcie (nie)uczestnictwa na dwa momenty kontinuum, warto zastanowić się nad przesłankami stojącymi za postawami wyznaczającymi jego krańce. Nasuwa się konstatacja, że w większości motywacje do uczestnictwa w wydarzeniach oferowanych przez instytucje muzyczne są uniwersalne i towarzyszą wielu osobom bez względu na segment, do którego zostały zaklasyfikowane. Powszechna jest potrzeba oderwania się od spraw codziennych czy chęć spędzenia czasu z innymi w atrakcyjny sposób. Podłączeni wszystkożercy istotnie częściej niż przedstawiciele innych segmentów czuli potrzebę rozrywki, a zanurzeni w kulturę poszukiwali wiedzy oraz wrażeń estetycznych.

Powody nieuczestnictwa w koncertach muzyki poważnej czy przedstawieniach operowych są w mniejszym stopniu jednolite. $Z$ uwagi na różną wielkość segmentów możliwość wychwycenia czynników wpływających na nieuczestnictwo była różna. Pragmatycy istotnie częściej niż przedstawiciele pozostałych segmentów wskazywali na brak zainteresowanie wydarzeniami związanymi z muzyką poważną, brak pieniędzy, ale również problemy zdrowotne czy niepełnosprawność. Podłączeni wszystkożercy sygnalizowali, że powodem jest towarzyszące im w tych miejscach poczucia niedostosowania, a zanurzeni w kulturę częściej niż inni sygnalizowali trudności w wybraniu konkretnego wydarzenia.

Naszym zdaniem największy potencjał do zwiększenia uczestnictwa w kulturze instytucjonalnej mają podłączeni wszystkożercy. Nasz wniosek dotyczący segmentu podłączonych wszystkożerców wzmacnia konstatacja badaczy uczestnictwa 
w kulturze w małych i średnich miastach. Wyodrębnili oni podobny segment, czyli "cyfrowych indywidualistów”, do którego przynależy $11 \%$ badanej przez nich próby. Są to osoby młodsze i lepiej wykształcone w porównaniu z pozostałymi kategoriami (nie)uczestników, czytające i przejawiające potrzeby kontaktu z kulturą. Należą one zatem do grupy potencjalnych „bywalców” instytucji, jednak ich praktyki kulturalne ograniczają się do cyberświatów [Szlandak 2019: 83]. Podłączonych wszystkożerców widzimy jako osoby przeciwstawiające się klasycznym formom wyrazu, czy tradycyjnym stylom życia. Jako twórców odrębnego sposobu bycia, w którym media cyfrowe stoją w centralnym miejscu. Internet jest dla nich nie tylko ważnym źródłem informacji, ale również środkiem wyrazu i samorozwoju. Odnosząc się do sygnalizowanego przez ankietowanych z tego segmentu dyskomfortu towarzyszącego udziałowi w wydarzeniach kulturalnych, powodowanego na przykład zasadami etykiety, wyrażającymi się poprzez wymagania dotyczące stroju czy zachowania, wydaje się, że jest to przeszkoda stosunkowo łatwa do przekroczenia. Bariera, która może być niwelowana przez rozmaite działania instytucji kultury.

Warto podkreślić, że powody nieuczestnictwa towarzyszące wyjściom do opery, czy koncertom muzyki klasycznej, a o takich mówimy w niniejszym artykule, nie odbiegają od tych wyłaniających się z innych badań nad uczestnictwem w kulturze. Mamy na myśli powody wynikające między innymi z wieku, zasobności portfela, wykonywanego zawodu czy oceny stanu zdrowia [por. Płachecki red. 2019]. Biorąc pod uwagę to, że powody nieuczestnictwa deklarowane przez ankietowanych korespondują z rzeczywistymi barierami, należy zastanowić się, jakie czynności należy podjąć w celu niwelowania tych barier. Jednocześnie trzeba wziąć pod rozwagę, że przedstawiciele segmentów $\mathrm{w}$ różnym stopniu są zainteresowani uczestnictwem w wydarzeniach kulturalnych. Zidentyfikowanie istniejących „subświatów” [zob. np. Szlendak 2017: 70], z myślą o szukaniu potencjalnej publiczności, może inspirować do podjęcia refleksji nad tym, jak włączać je w prowadzone działania i zaprosić do spotkania z innymi „subświatami”, na przykład tymi, które już są publicznością naszej instytucji. Proponowana segmentacja jest uproszczeniem skomplikowanej i wielowymiarowej rzeczywistości. Jej budowa miała na celu zaprezentowanie wspólnych cech grup, by umożliwić dobór odpowiednich działań dla każdej z nich oraz by instytucje kulturalne mogły proponować rozwiązania uwzględniające potrzeby i motywacje poszczególnych segmentów.

\section{Bibliografia}

Afeltowicz Ł. et al. (2018), Efekt Bilbao / kult cargo. Nowe instytucje kultury w Polsce, Elbląg: Wydawnictwo Biblioteki Elbląskiej.

Aktywności Polaków w 2018 roku (2019), Centrum Badania Opinii Społecznej. 
Bachórz A. et al. (2016), Kulturalna hierarchia. Nowe dystynkcje i powinności w kulturze a stratyfikacja społeczna, Gdańsk: Instytut Kultury Miejskiej.

Bachórz A., Ciechorska-Kulesza K., Czarnecki S., Grabowska M., Knera J., Michałowski L., Stachura K., Szultka S., Olbracht-Prądzyński C., Zbieranek P. (2014), Punkty styczne: między kultura a praktyka (nie)uczestnictwa, Gdańsk: Instytut Kultury Miejskiej

Bachórz A., Stachura K. (2015), W poszukiwaniu punktów stycznych. Rekonstrukcja dyskursu o problemach nieuczestnictwa w kulturze, Gdańsk: Instytut Kultury Miejskiej.

Badanie segmentacyjne uczestników kultury (2016), Warszawa: Muzeum Historii Polski, Muzeum Historii Żydów Polskich POLIN, Narodowy Instytut Fryderyka Chopina / Smartscope.

Gąsior M. (2013), Stosunek konsumentów do transakcji zawieranych przez internet - ujęcie segmentacyjne, [w:] G. Rosa, A. Smalec (red.), Marketing przyszłości. Trendy. Strategie. Instrumenty. Konsument jako uczestnik procesów rynkowych i odbiorca komunikatów marketingowych, Szczecin: Uniwersytet Szczeciński, s. 159-171.

Gdula M., Lewicki M. (2019), Sztuka dla wszystkich? Reguły upowszechnienia i ekskluzywności w praktykach uczestnictwa, [w:] T. Płachecki (red.), Relacje i różnice. Uczestnictwo warszawiaków i warszawianek w kulturze, Warszawa: Teatr Scena Prezentacje, s. 92-103.

Jacyno M., Lewicki M., Kukołowicz T. (2018), Kultura na peryferiach, Warszawa: Narodowe Centrum Kultury.

Koryś I., Kopeć J., Zasacka Z., Chymkowski R. (2017), Stan czytelnictwa w Polsce w 2016 roku, Warszawa: Biblioteka Narodowa.

Kotler P. (1994), Marketing. Analiza, planowanie, wdrażanie i kontrola, Warszawa: Gebethner. Kotnarowski M. et al. (2019), Tradycyjni, masowi, superkulturalni? Segmentacja warszawiaków $i$ warszawianek pod względem uczestnictwa w kulturze, [w:] T. Płachecki (red.), Relacje i różnice. Uczestnictwo warszawiaków i warszawianek w kulturze, Warszawa: Teatr Scena Prezentacje, s. 104-115.

Kotnarowski M., Piechocki P. (2019), Co wpływa na zaangażowanie w kulturę?, [w:] T. Płachecki (red.), Relacje i różnice. Uczestnictwo warszawiaków i warszawianek w kulturze, Warszawa: Teatr Scena Prezentacje, s. 34-49.

Kowalski J., Kobyliński P. (2014), Uczestnictwo w kulturze - segmentacja, [w:] Raport Polskiej Izby Książki z projektu badawczego „Kierunki i formy transformacji czytelnictwa w Polsce”, Warszawa: Polska Izba Książki.

Kwiatkowski P.T. et al., Założenia badawcze: Werner M., Kukołowicz T., Modzelewska M. (2016), Raport z badania zrealizowanego na potrzeby Wieloletniego Programu Rzadowego „Niepodległa '18', Warszawa: Narodowe Centrum Kultury / TNS POLSKA.

Łukasiewicz P. (2015), Badania komercyjne a statystyka kultury, [w:] T. Kukołowicz (red.), Statystyka kultury w Polsce i Europie. Aktualne zagadnienia, Warszawa: Narodowe Centrum Kultury.

Maciejczak-Kwiatkowska Z., Modzelewska M., Retko-Bernatowicz M., Węglarska K., Pol G., Bąk A., Wiśniewski R., Wrotnowska-Gmyz E. (2019), Stanisław Moniuszko - znany, lecz nieobecny. Opinie Polaków na temat twórczości i postaci kompozytora w dwusetna rocznice jego urodzin, Warszawa: Narodowe Centrum Kultury. 
Peterson R., Kern R. (1996), Changing Highbrow Taste: From Snob to Omnivore, „American Sociological Review", vol. 61, no. 5.

Punj G., Stewart D.W. (1983), Cluster Analysis in Marketing Research, „Review and Suggestions for Application Journal of Marketing Research” 1983, Vol. 20, No. 2.

Retko-Bernatowicz M. (2017), Aktywność kulturalna Polaków - próby segmentacji, Rocznik Kultury Polskiej, Warszawa: NCK.

Smith W.R. (1956), Product Differentiation and Marketing Segmentation as Alternative Marketing Strategies, „The Journal of Marketing” 1956, Vol. 21, No. 1, s. 3-8.

Szlendak T. (2017), Sześć zjawisk w polskiej kulturze wartych przemyślenia. Dobrych i takich sobie, [w:] C. Obracht-Prondzyński, P. Zbieranek (red.), Pomorskie poszerzenie pola kultury. Dylematy, konteksty, działania, Gdańsk: Nadbałtyckie Centrum Kultury.

Szlendak T. (2019), Praktyki pozametropolitalne: Uczestnictwo w kulturze w małym i średnim mieście, „Studia Socjologiczne” 2 (233), s. 61-98.

Tyszka A. (1971), Uczestnictwo w kulturze. O różnorodności stylów życia, Warszawa: Państwowe Wydawnictwo Naukowe.

Tyszka A. (1981), Partycypacja kulturalna, „Teksty: Teoria literatury, krytyka, interpretacja”, nr 3 (57), s. 137-142.

Walesiak M. (2000), Segmentacja rynku. Kryteria i metody, Wrocław: Akademia Ekonomiczna im. Oskara Langego we Wrocławiu.

Wiśniewski R., Kukołowicz T. (2017), Pięć kierunków poszerzania pola kultury, czyli uwagi o współczesnej polityce kulturalnej, [w:] C. Obracht-Prondzyński, P. Zbieranek (red.), Pomorskie poszerzenie pola kultury. Dylematy, konteksty, działania, Gdańsk: Nadbałtyckie Centrum Kultury. 